\title{
Innovation and Venture Capital Policy in Brazil and South Africa
}

\author{
Krista Tuomi', Lopo De Castro Neto²
}

\begin{abstract}
This paper examines what constrains and what augments innovation in emerging markets, with a focus on the role of venture capital. It analyses what policy options are open to the government to facilitate innovation. To do this it looks at two country case studies: Brazil and South Africa.
\end{abstract}

Keywords: brazil; south africa; innovation; venture capital; policy constraints.

American University. 4400 Massachusetts Avenue, NW.Washington DC 20016.

' Professor in the International Economic Policy program at the School of International Service, American University. Policy analyst with a focus on foreign direct investment, governance capacity and Africa. e-mail: tuomi@american.edu

${ }^{2}$ Student at American University's School of International Service specializing in International Economic Policy with a regional focus on Latin America and Brazil. Specific interests include industrial policy and international trade.e-mail: I.decastroneto@gmail.com 


\section{Innovation and Venture Capital Policy in Brazil and South Africa}

Technological progress is a key determinant of sustained long-term economic growth. Conceptually it can be divided into absorption and innovation. With respect to a country, absorption occurs where technology is diffused from another country and adopted as is. Innovation is the development and commercialization of unproven technologies and untested processes and products. Although separate in theory, the concepts are linked. As noted by Goldberg et al (201 I: 12):"The ability of an economy to research and develop new technologies increases its ability to understand and apply existing technologies. Vice versa, the absorption of cuttingedge technology inspires new ideas and innovations."

This paper examines what constrains and what augments innovation in emerging markets, with a focus on the role of venture capital. It analyses what policy options are open to the government to innovation. It looks at two country case studies: Brazil and South Africa. Although Brazil enjoys higher total factor productivity (TFP) scores than South Africa, both countries lag substantially behind Asia, which is rapidly catching up to the developed world (see Table I).

\section{What determines Innovation?}

Theory points to a number of factors that determine innovation. A firm must not only have the incentive to invest, but also the capacity. The incentive to invest in innovation is multi-faceted and heavily reliant on the overall investment climate especially aspects such as openness, competition, infrastructure, and property rights.

\section{Incentive to Invest}

As noted, much innovation is inspired by available technology. An important aspect of innovation is therefore, access to international breakthroughs in products, processes and blueprints. This is diffused to other countries through a number of channels, including: trade, foreign direct investment, licensing, and human capital.

With respect to trade, importers can learn from the technological content both of imported capital goods and of inputs (Lederman, 20 I0; MacGarvie, 2006). Exporters, on the other hand often upgrade through exposure to world class competition and knowledgeable buyers, who share product designs and production techniques with them. ${ }^{3}$ Foreign Direct Investment (FDI) is another important transmission mechanism with technology transferred between countries via imitation, labor turnover and vertical linkages (Saggi, 2002).

The role of competition is complex. The presence of firms with superior products can either spur incumbents to invest in more $R \& D$, or if they lag behind the technological frontier, reduce costly innovation out of fear that the competition would erode innovation rents (Lederman, 2010). High-trade environments can to tip the balance in favor of innovationspurring competition however, as can relative R\&D levels. ${ }^{4}$

\begin{tabular}{|l|l|l|}
\hline Regions and income groups & $\begin{array}{l}\text { TFP relative to that of } \\
\text { the U.S., 2005 (Index, } \\
\text { U.S. }=100)\end{array}$ & $\begin{array}{l}\text { Annual TFP growth, } \\
\text { I990-2005 (Annual } \\
\text { percentage change) }\end{array}$ \\
\hline East Asia and the Pacific & 8.4 & 5.1 \\
\hline Europe and Central Asia & 21.7 & 2.2 \\
\hline Latin America and the Caribbean & 19.3 & 0.2 \\
\hline Middle East and North Africa & 13.3 & 0.5 \\
\hline South Asia & 5.8 & 2.3 \\
\hline Sub-Saharan Africa & 5.6 & 0.2 \\
\hline High-income OECD & 77.1 & 1.3 \\
\hline High-income non-OECD & 53.1 & 0.7 \\
\hline Upper-middle-income & 23.7 & 1.2 \\
\hline Lower-middle-income countries & 9.6 & 3.2 \\
\hline Low-income countries & 5.2 & 1.7 \\
\hline Source: GEP, 2008. & & \\
\hline
\end{tabular}

Table I:TFP growth in SSA in international comparison, 1990-2005

(Source: Goldberg et al., 201 I)

ISSN: 07 I8-2724. (http://www.jotmi.org) 
Property rights play a nuanced role in driving innovation in emerging markets. As noted by Cimoli et al (201 I: 3) "If there is a robust historical fact, it is the laxity or sheer absence of intellectual property rights in nearly all instances of successful catching up." However, many empirical studies find that innovation and diffusion tend to be higher in countries with better protection of property rights. Part of the answer to the discrepancy may lie in how diffusion took/ takes place. For countries with the skill level to reverse engineer and rapidly commercialize products, weak property rights may hasten upgrading. For those where most diffusion occurs through multinationals, weak property rights may hamper it. Multinational firms are especially cautious of transferring anything but mature technology to subsidiaries in countries with weak property rights. Patents may also promote the diffusion of technological knowledge through licensing agreements or other forms of market mediated technology transfer (Cimoli et al. 20I I).

Furthermore, as the world becomes more integrated and more countries harmonize standards and join international institutions such as the WTO, the importance of property regimes may increase. The desired level of property rights is therefore a time and country dependent variable. For countries where the majority of diffusion and innovation occurs through FDI and linked firms, the level of patent law and property rights should be fairly comprehensive. This does depend, however, on the capacity of local firms to successfully imitate the technology,AND on the type of technology itself.Where it is embedded in organizational processes and people, it is harder to copy and therefore less protection is necessary. Moreover, the "anti-commons" problem is becoming more prominent, especially in areas like biotechnology. Strong patent regimes can hinder development due to the time and cost involved in fighting lawsuits related to aspects of the product or production process. ${ }^{5}$

\section{Demand Drivers}

Recently there has been renewed focus on the importance of the demand side of the innovation equation, both of consumer demand and of public procurement. Long recognized as a driver of innovation in defense, construction, health care and transport, the potential of broader public procurement is increasingly emphasized. Recent papers by the European Commission have noted that procurement can spur innovation and create a lead market, especially in countries where the state is an important purchaser. The critical mass often entailed in a state contract can reduce market risk for firms and enable economies of scale and learning.A good example is that of the NUTEK and STEM energy agencies in Sweden. These agencies instituted a scheme aimed at diffusing energy-efficient technologies. Public procurement acted as an 'ice-breaker' and catalyst as the bodies mobilized private demand through awareness measures, discussions with users and occasionally subsidization of procurers. (Private sector demand is, of course, also stimulated through regulation and standard setting.) It is obviously important that such procurement does not dissolve into an attempt to "pick winners". A number of strategies can mitigate this tendency. For instance, the UK's Environmental Innovation Advisory Group assesses long term demand for products and services and signals these to industry early in the procurement process. This allows the most economically efficient firms to rise to the challenge. Another useful initiative is that of PIANO in the Netherlands, which created a network for procuring agencies to share good practice and new approaches (Edler and Georghiou, 2007).

\section{Capacity}

In addition to access, firms need the capacity to absorb and innovate. This capacity depends both on firm skill level and access to funds for R\&D and commercialization. Skill level includes the education level of the workforce and management, and experience in rapid adaptation of products and processes. This is facilitated by a country and firm-level environment that encourages creativity, change and flexibility. An example of this interplay can be seen in broadband provision, which is often touted as an important innovation factor. As Bloom et al (2012) note however, firms from some countries are better able to capitalize on this. Their data show that US firms make more productive use of technology than European firms, partly because US managers are more aggressive in rewarding high-performing staff and removing underperformers.

Aspects such as effective bankruptcy laws, multiple sources of finance, a relatively diverse and large private sector as a percentage of GDP, tax breaks for R\&D, and good government service delivery are all important. In countries where some of these fall short (poor education and infrastructure, thin banking system), a targeted source of government funding and support can help "fill the gap" while the long-term issues are addressed. It is important to remember, however, that in many cases, public funding is at best a catalyst. As noted by Blankley and Moses (2009), public funds are not that important for the majority of innovative firms in the countries where data is available. R\&D is considered a vital business activity for these firms and they are reluctant to seek public funding if it would expose their technology to the competition. Many firms collaborate on R\&D (with other firms and with academia) given the uncertain and imperfectly appropriable nature of much research. The most important links with respect to innovation are business to business ones (either with other companies, suppliers or customers) which are difficult for governments to simulate. This quandary ties into the ongoing policy debate around 
"innovation systems" and the argument for a systemic approach to innovation at the national level. A systems approach is based on the premise that firms do not innovate in isolation but rather in complex interactions with other firms, clients, universities, and government research institutes. As noted earlier, this relationship is nuanced. Some types of interaction (private and client based) can be more efficient than others, and some types of firm (foreign-owned subsidiaries) rely far less on interactions with third parties (Almeida and Fernandez, 2008).

The argument for more government involvement is stronger where firms struggle to appropriate R\&D outlay. Although a case may be made for direct public funding, it is often far better for government to create an enabling environment than to be a direct participant. One way of doing this is for the government to encourage, or at least not frustrate, the domestic and foreign venture capital industry. Foreign venture capital firms are starting to increase their abroad acquisitions. They can face a number of "new issues" in domestic markets. These include: bureaucracy that can slow the rapid start-up growth that seed investors prefer; cultural barriers (such as the difficulty in recruiting employees to work for an unknown company in exchange for equity); and the difficulty in exiting through large initial public offerings in countries where investors like to buy well-known names. As such, many American venture investors often prefer to bring in a local partner to navigate the domestic market (Economist, 20I2).

Recently some other interesting factors have been added to the list of innovation determinants. For instance, a highskilled diaspora can often act as an important technology and growth conduit for home countries. For example, the Indian diaspora has contributed to the growth of the information technology and outsourcing sectors and the Taiwanese diaspora to the venture capital industry, helping finance highrisk entrepreneurial activities in the technology sector (Noland and Pack, 2003). In fact, the Indian government permits software companies to grant stock options to attract qualified staff from abroad. Chandra and Kolavalli (2006) note, however, that technically skilled professionals require more than a good salary. They require a working environment of limited bureaucracy and networks of similarly qualified scientists and professionals. To some extent the Taiwanese government engendered this through the creation of science and technology parks and the development of industrial clusters.

The level of entrepreneurial talent is another "hot" area. Although it is widely considered important for innovation, there is little consensus on how best to develop it. Some place weight on a "tradition of entrepreneurship" while others suggest that it can be fostered by investments in management or business education (e.g. India). Chandra and Kolavalli (2006) again use recent experience in Taiwan and Chile as examples. Since private firms were unwilling to start and nurture businesses in high-risk sector with new technologies, government agencies incubated the first few firms until they became economically viable, at which point they were sold to private buyers. They highlight a number of reasons why public support in these countries was relatively successful. These include: political commitment; export-conditional public support (which rewarded winners and punished losers); a policy of targeting faster growing industries (as opposed to trying to pre-pick winners); a policy of reducing support in the face of industry growth; unrestricted competition among domestic firms; and the enforcement of property rights.

\section{The South African Situation}

Relative to other African countries, South Africa conducts a fairly large amount of R\&D, $50 \%$ of which is funded by businesses. This has helped a small number of large firms remain close to the world technological frontier, especially in mining, mining related industry and some IT applications. ${ }^{6}$ This position is being eroded, however, by skills shortages and adverse regulation, among other factors. Furthermore, there is little cutting edge technological innovation beyond this sector (Kaplan, 20I2). As shown by Table I,TFP scores and growth rates are far below the rest of the world. Ta-

\begin{tabular}{|l|l|l|l|l|}
\hline & 2001 & 2003 & 2005 & 2007 \\
\hline Brazil & 441 & 496 & 588 & 658 \\
\hline Russia & 3460 & 3365 & 3230 & 3274 \\
\hline India & 110 & -- & 136 & -- \\
\hline China & 581 & 667 & 856 & 1077 \\
\hline $\begin{array}{l}\text { South } \\
\text { Africa }\end{array}$ & 312 & 303 & 362 & 396 \\
\hline
\end{tabular}

Table 2. Researchers in R\&D per million population; BRICs (200I- 2007)

(Source:World Development Indicators)

ISSN: 07 I8-2724. (http://www.jotmi.org)

Journal of Technology Management \& Innovation (c) Universidad Alberto Hurtado, Facultad de Economía y Negocios. 
ble 2 shows a comparison of researchers in R\&D per million of the population for the BRICS countries, highlighting the SA stagnation. Other measures of innovation confirm this. While the other BRICS countries have shown a hefty increase in the patent application figures, recent South Africa patent activity has been relatively negligible. Moreover, in emerging high-technology areas such as biotechnology, there are few patents and these tend to be of low quality. With respect to another measure of innovation, licensing receipts, South Africa has seen declines of $30 \%$ over the last two decades while the other BRICS have enjoyed significant growth (Kaplan, 20I2).

South Africa's sluggish innovation is directly related to its skill shortage. There are a number of reasons for this shortage starting with the persistent effects of unequal access to quality schooling under the apartheid system. This is compounded by the failure of the technical and vocational education and training (TVET) system and higher education to keep pace with the increasing demand for skilled labor. These institutions are characterized by both low enrolment and low completion rates, partially due to lack of quality preparatory schooling. Complicating the matter is the poor performance of the National Skills Fund, which levies businesses to fund TVET, and the Sector Education and Training Authorities (SETAs), mandated to support business training. These are widely regarded by business to be bureaucratic and dysfunctional (Goldberg et al, 20I I).

The skills problem dominated the concerns of South African innovators and potential innovators in a study by Goldberg et al (20l I). Firms noted that high labor costs and regulation worsened the skills shortage, as even higher wages were required to retain the few skills available. In fact, unit labor costs in South Africa are estimated to be between 35\% and $40 \%$ higher than in Brazil and China (Kaplan, 2012). They were also precluded from importing talent from abroad due to difficulties in obtaining work visas. Moreover, in the face of competition from eastern imports some companies were forced to produce a wide range of products, at lower unit quantities than their minimum efficient scale larger.This only increased complexity and skill demand, since it was difficult for labor to develop the requisite technological competence. As such, many companies said that they were being forced to move some of their operations overseas.

Difficulties in accessing export finance and venture capital were also highlighted, from both private and public sources. (Very few firms were able to get preferential finance from the Industrial Development Corporation (IDC), the major public funder of start-up capital.) Some concerned firms also cited that substantial collateral was required for bank loans. The South African VC asset class is a very small component of the overall market for equity investments, compared to other similar sized countries. It is particularly challenging for biotech and IT investors, given constraints related to exchange control and regulatory impediments to taking IP offshore. As such, the current outlook for private VC capital is muted (see Box I for an overview of SA Venture Capital).

With respect to linkages with research institutions, IT firms noted that they were reluctant to work with science councils and engage in collaborative research, given the government's insistence on retaining intellectual property rights. Because of IP restrictions, a number of South African IT firms with potential global prospects have not been able to move any IP offshore, making it difficult to access international venture capital to fund expansions abroad. Also emphasized was the effect of government procurement, black economic empowerment (BBE) legislation. This was perceived as significantly

-The SA private equity and venture capital (VC) industry have over $\$ 14.3$ billion under management, with VC contributing about $\$ 500$ million.

-About $4 I \%$ of transactions involve the life sciences and $27 \%$ involve the IT sector.

- Government funds account for $35 \%$ of all investments by value (or $31 \%$ by number of transactions). These include: the Industrial Development Corporation (IDC) ${ }^{7}$, the Innovation Fund, Cape Biotech, LifeLab, BioPad and PlantBi, all four being former instruments of the Department of Science and Technology now amalgamated into the Technology Innovation Agency (TIA).

-Although the skills and professionalism in the VC industry have grown significantly in the last ten years, a number of problems are still prominent: poor quality of investment proposals and business plans from the business community, heavy reliance on networks and contacts, opaqueness, inability to exit by formal public listings due to limited liquidity, little take-up by the VC community of the 2008 tax incentive, and lack of consideration of the role of VC in the drafting of the Intellectual Property from Publicly Financed IP Act.

-The single biggest impediment to VC is exchange regulation on the flow of capital (both money and IP). Given the small size of the SA market, to minimize risk VC investors need to be able to invest in projects with international potential. This is normally achieved by taking the venture offshore. Current exchange controls mean investors have to sell IP abroad on an arm's length basis. This limits the incentive to invest in SA projects and means $V C$ investors spend unnecessary resources to try and internationalize in spite of constraints.

Box I:The South African Venture Capital Industry (SAVCA, 2010) 
constraining development (Goldberg et al, 20II) ${ }^{8}$ Government procurement was seen to be inefficient, opaque and poorly specified. The risks associated with tendering are particularly severe for small firms, as are the equity requirements of BBE legislation (Kaplan, 20I2).

\section{Current Public Initiatives}

Apart from the afore-mentioned VC initiatives of the IDC, South Africa has a few other measures in place aimed at fostering innovation. Tax incentives are offered in terms of section II(d) of the Income Tax Act No. 58. The incentive consists of a deduction of $150 \%$ in respect of current expenditures on eligible scientific or technological R\&D and an accelerated depreciation of capital assets (including buildings) used for purposes of scientific and technological R\&D over three years at the rate of 50:30:20. ${ }^{9}$ Only a few large firms have made use of this incentive as the details, evidence and paperwork required are preclusive for most small and medium firms.

Since small firms and start ups are less able to benefit from tax incentives (they have less taxable income), South Africa, like many other countries has matching grant program. ${ }^{10}$ The Support Program for Industrial Innovation (SPII) in South Africa targets product/process development that represents a significant technological advancement and has a commercial advantage over existing products. Assistance of between $50 \%$ and $85 \%$ of the actual direct development costs is granted up to a maximum grant of RI,000,000 (Goldberg et al, 20I I).Assistance is also provided through the Technology Innovation Agency, which was created to help bridge the gap between research that is produced locally and the realization of this research into commercial undertakings.

Although the integration of academic and industrial research is suboptimal in South Africa, there are a few promising initiatives in this area. The Technological Human Resources for Industry Program (THRIP) managed by the Department of Trade and Industry serves both to promote training that is appropriate for firms and to enhance industry-university collaboration (OECD, 2007). THRIP supports projects on a cost-sharing basis, increasingly targeting small and empowerment firms.

With respect to the commercialization of public funded research, 2008 saw the induction of the 'Act on Intellectual Property Rights from Publicly Financed Research', modeled on the US Bayh-Dole Act. It gives institutions the responsibility to seek protection for their IP in exchange for the right to own equity and exploit it. All research with commercial possibility has to be registered with the National Intellectual Property Management Office (NIMPO) along with a plan on how to commercialize it. (This does not involve research that is wholly privately funded or that is wholly funded by a foreign firm.) NIMPO has to approve the plan and revenue is to be shared with inventors. Government is given a "free license" to the IP should this be in the national interest.

\section{The Brazilian Situation}

Despite having a low level of innovative output when compared to OECD countries, Brazil has seen a steady growth in technological innovation over the last decade. Since 1990 the number of scientists in the country, as well as the country's share of scientific output have tripled (Brandao et al, 2006). Alongside the growth in basic scientific research there has been a rise in private sector firms engaging in innovative activity. This is evident in the rise of the country's "innovation coefficient" as measured by the Brazilian government statistical bureau, IBGE. In their latest survey of 106 800 firms, $38.6 \%$ were reported as engaging in innovative activity, up from $34.4 \%$ in the $2003-2005$ period (IBGE, 2008: 36). Despite this increase in private sector participation, the Brazilian state is still responsible for around $60 \%$ of expenditures on R\&D (Salerno, 2008). Furthermore only $26 \%$ of scientists are employed by businesses, compared to figures of around $80 \%$ for the US and Korea (De Brito Cruz and Mello, 2006: 95). Thus the advances made by Brazil in innovation are still heavily reliant on government support. If growth in technological innovation is to accelerate, Brazil needs to maintain and deepen its favorable macroeconomic climate. This must be coupled with a change in perception by local business that research is something conducted by academia with government funding.

\section{The Brazilian National Innovation System}

A national innovation system is the collection of "government policy-making infrastructure, the university and government laboratory system, tax laws, and intellectual property laws, among others" (Reicheit, 2007: 4). In Brazil, a wide variety of governmental institutions work to promote or create innovation. The main governmental institution that sets policy regarding technological innovation is the Ministry of Science and Technology (MCTI). In coordination with other ministries, the MCTI sets the "national strategy on science, technology and innovation" (MCTI, 20II). The MCTI distributes its funds and set the research expenditure of other federal institutions according to this strategy including: funding for federal universities (e.g. UFRJ, UFMG), federal research institutes (e.g. CNPQ, Embrapa) and federallyowned firms (e.g. BNDES, Petrobras and Electrobras). The large federal financier of innovation projects and research, FINEP, is also under the auspices of the MCTI and has the largest single budget directed to innovation in Brazil." Since 
1999, FINEP has set up 14 "sectoral funds" where non-repayable funds are dispersed to areas which the government has selected for development. These funds are inflexible and are only intended for not for profit universities and research institutions. For-profit enterprises are only allowed to collaborate with the main recipient of the fund. ${ }^{12}$

A combination of new innovation laws (200I, 2004, 2005), are starting to provide more of business slant to FINEP (Jardim, 20I2). Credit lines have been set up for businesses to request loans at lower than market interest rates under a program called 'Inova Brasil'. This program finances $90 \%$ of the costs of projects that are planning to launch a new product, service or process. Furthermore a new sectoral fund has been set up. The 'Verde-Amarelo' fund is designed for projects with private firms as partners. As with the other sectoral funds, however, private firms do not directly receive funds for their R\&D projects but must partner with a public university or research institution.

Although since 2005 the National Innovation System has been moving away from a statist approach to innovation policy, it is still clear that the public sector is dominating investment and the direction of innovation. ${ }^{13}$ In lagging behind the OECD rates of investment in R\&D, Brazil has shown the "weakness of state power, the inefficiencies of public institutions and a complex bureaucracy that obstructs concrete actions" (Arbix, in Sennes, 2009: 20). The fragmented sources of funding from FINEP with its many lines of funding for different purposes; the multiple credit lines of BNDES; and the multitude of government funded research institutes and 63 federal universities have all led to much overlap and redundancy in the funding and executing of similar research projects. This has, in turn, led to a second problem mentioned by Arbix (in Sennes, 2009) - the lack of coordination between government institutions, universities and private initiatives. All of this is compounded by a great amount red tape which slows down commercialization. As was mentioned in the introduction, the need for greater private sector participation is clear.

The tax system forms another important aspect of the innovation environment. In terms of the current legal and fiscal framework, several laws enacted in between 2004 to 2007 greatly expanded previous tax incentives for the creation of innovation as well as other benefits. ${ }^{14}$ Some of the incentives created were:

i. A $50 \%$ reduction on the taxes on industrialized goods, called "IPI" for the purchase of capital goods necessary for $R \& D$.

ii. All expenditures made on innovative research can be deducted from taxes on income. ${ }^{15}$ iii. Contracts made with other smaller companies and/or research institutes that relate to innovation can be included as 'internal R\&D spending' and thus included in the tax deduction on income (Salerno, 2008: 35).

These regulatory changes have been lauded by a number of industry experts as a big step forward and a rare case of the Brazilian state reducing its footprint in the field of innovation. ${ }^{16}$ For example, a number of VC professionals have highlighted the way the 2004 law changed the terms by which business can partner with public research institutions and public universities. The change has allowed for "publiclyaffiliated researchers to find capital and investors to make new products with their research" (Castro, 20I2). The law also allows for a smoother transfer of knowledge from public researchers to companies, allowing business incubators to be set up in universities (De Morais, 2008: 72; IPEA, 2008: 2). The 2004 law has come fairly late, however, as many other OECD countries enacted similar laws decades ago. For instance, South Korea has had laws promoting innovation as far back 1967, while the US Bayh-Dole Act dates back to the 1980s (Matias-Pereira and Kruglianskas,2005: 6). Moreover, outside of the recent regulation changes, the general tax burden in Brazil is extremely high, at around $38.8 \%$ of GDP (Rodriguez, 2008: 39). This hinders all start-ups, including innovation intensive ones.

\section{Brazilian Venture Capital Industry}

The earlier definition of national innovation systems is missing a key component. If the purpose of innovation is "the generation of wealth that comes with high-tech products" (Salerno, 2008: 17), then some form of start-up or venture capital is essential to turn "knowledge and ideas into products and services" (Arbix, in Sennes, 2009: 25). Venture capital has made significant advances in the country over the past decade growing from eight $\mathrm{VC}$ fund managing companies in 1994 to 180 VC fund managing companies today. According to the sector's Brazilian association, ABVCAP, invested capital in 2004 was only $\$ 5.6$ billion. This grew fivefold to $\$ 38$ billion in $2010 .{ }^{17}$ In 2004 , out of the 304 companies that received investments of the VC or PE type, 204 were recipients of venture capital investments, which shows a strong preference for start-ups as opposed to established enterprises (Salerno, 2008: 85).

A great deal of the growth in VC in Brazil can be attributed rather broadly to the macroeconomic environment that has been fairly stable since the mid-1990's, with low inflation rates and steady economic growth. Some growth may also be due to legislative changes that allowed for greater public-private partnerships. ${ }^{18}$ Other changes to the regulatory framework of theVC industry have proven just as important, however. A 2006 law reduced taxes on income made with 
VC by foreign investors to zero, provided they get taxed at least by $20 \%$ in their home countries. ${ }^{19}$ Furthermore the Brazilian equivalent to Securities and Exchanges Commission , the CVM, set new ownership mechanisms that allowed limited partnership and holding companies to be set up. ${ }^{20}$ More narrowly, VC growth has been aided by Inovar, the previous mentioned effort of FINEP in conjunction with the IDB. Before its creation private equity was performing fairly well, while $\mathrm{VC}$ was languishing. Realizing that the smaller start-ups can be more innovative than the larger companies that private equity usually deals with, FINEP decided to address some of the problems with VC capital formation including: small numbers of domestic fund managers; an unwillingness by pension funds to invest in VC; a disconnect between investors and start-ups; and the fact that few Brazilian companies were familiar with VC. As such, FINEP introduced a number of measures aimed at fostering a Brazilian VC culture. First they instigated a series of panels on VC funds, to assess VC funds and provide advice on how to improve. Second, they organized forums with the intention of educating investors, start-up owners and researchers on VC. Lastly, they held training workshops on due diligence and other topics. The first phase of Inovar was so successful that a second phase, 'Inovar II' was initiated in 2007. These forums, panels and training sessions, which still occur regularly, had a cost of $\$ 13$ million for both phases and facilitated more than $\$ 1$ billion in investment (Leamon and Lerner, 2012: 17). Regardless of the actual value of the deals that occurred as a direct consequence of the program, the real value of Inovar was to establish a "necessary inter-personal relationship network between researchers, investors and start-ups" (Castro, 2012). Because these initiatives were so successful a private non-profit, ABVCAP, was created to gradually replace the publicly run Inovar program and continue its work.

Despite the progress that has been made in the last decade, there are several issues that still hinder VC in Brazil. Evidence of this is the fact that $76 \%$ of firms still finance their own R\&D projects and only $4 \%$ were financed by a separate source of private capital (IBGE, 2008:82). Finance is not reaching all of those that could effectively use it. On the supply side, the large Brazilian pension fund system, estimated at about $\$ 324$ billion, has yet to invest wholeheartedly in venture capital (De Carvalho, Netto and Sampaio, 2012:4). As noted by Jardim (20I2), a VC fund manager in Brazil "if $2 \%$ of those funds were invest in VC, there would be a revolution in the industry". The main hindrance is the fact that the short term interest in Brazil, although on a downward trend, is still very high, ranging from $15-20 \%$ annually, with low risk (Leamon and Lerner, 2012: 7). This makes investment in bonds far more appealing than other forms of investment.

\section{Policy Suggestions}

Given the established pre-conditions of technology diffusion and innovation, it is obvious that the 'first step' for any government is to ensure a good investment climate. In other words, ensure: openness to trade, an effective property right regime, a functioning judicial system, adequate infrastructure, and a fair tax and regulatory system. Infrastructure is particularly important as firms cannot even consider innovating while trying to operate with high costs and unreliable rail, harbor, power and IT provision.

A good investment climate not only helps local firms, but also encourages multinationals to "upgrade" their presence in the country. A conducive climate means that firms are more likely to perform R\&D activity in the country as opposed to just transferring technology from headquarters to local branches. Other policies can help diffuse technology through turnover. Programs such as bonded warehouses, back-to-back letter of credits and cash incentives can help local workers in multinationals start their own firms. ${ }^{21}$

\section{South Africa Specific Suggestions}

A number of problems with current initiatives have been highlighted. With respect to tax incentives it was noted that only few large firms have made use of this incentive as the details, evidence and paperwork required are preclusive for most small and medium firms. As such, Goldberg et al (20I I: 9I) suggest: "South Africa consider: (i) restructuring the R\&D tax incentive to make it easier to access, particularly for small firms; (ii) extending the list of qualifying expenditures to include more applied R\&D as appropriate for supporting technology absorption in sectors such as capital equipment; (iii) allowing a carry forward of the tax deduction so as to provide an incentive for R\&D activities whose returns do not materialize within one year."

Other tax incentives could be considered. Learning from Brazil, South Africa could increase the deductibility from corporate income tax of spending on R\&D to $200 \%$ of the value of purchases. According to current South African statutes, deductions of $150 \%$ on approved R\&D expenditures are allowed. In reality the complicated process and uncertainty in the approval process means that only a few large firms actually realize this.

With respect to financing, it was noted that the Technology Innovation Agency aims to bridge the gap between research that is produced locally and its commercialization through provision of funding, investment and venture capital support and brokering. Given the relative lack of innovative startups in South Africa, however, it is suggest that further support for the venture capital industry be provided along Bra- 
zilian lines. A first step would be to remove the capital gains on such funds by either residents or non-residents. Speeding up and simplifying the patent process would also help foster innovation among small firms.

The importance of academic-business linkages was noted earlier. Although initiatives like THRIP are laudable, substantially more linkages are needed. Goldberg et al (20II) suggest prioritizing company-led consortiums of companies and research institutions, and channeling the funding through the companies rather than the research bodies. This would help ensure that the research was market oriented rather than publication driven, and therefore be more fiscally sustainable.

Also of concern is the "free license" given to government in the 2008 'Act on Intellectual Property Rights from Publicly Financed Research', should the IP be deemed in the national interest. Given the concerns voiced by firms in the high technology sectors, the rights of research institutions and firms should be strengthened, allowing universities and public research laboratories the exclusive right to license to private firms.

With the correlation between trade and innovation, another way to boost innovation is through removing constraints to importing and exporting, especially for small firms. This could include some form of matching grant program to help reduce the cost of consultancy and certification required for exporting. With respect to imports, the learning process inherent in capital imports is enhanced when accompanied by training and on-site technical assistance. Smoothing the process of obtaining trainer work permits and visas is therefore vital. Possible solutions to this include a strategy that leans more heavily on the private sector. The public sector would concentrate on financing and quality assurance, and the private sector on service delivery (Goldberg et al, 20I I).

\section{Brazil Specific Suggestions}

One of the twelve directives of the current Brazilian administration is to "transform Brazil into a technological power" (Diretrizes de Governo, 2012). Achieving this goal will require the afore-mentioned actions of maintaining a stable economic environment, reducing the role of government in innovation and addressing the current bias toward basic research. It is vital that the Brazilian government nurture the environment of steady economic growth and the continuation of the downward trend in base interest rates. This is a pre-requisite for innovation to flourish in any country but is particularly relevant in Brazil, given its recent history. Fear of a return to "the lost decade" of the 1980's where inflation was in the thousands and growth near zero drives current economic policy. Since then interest rates have been kept high to keep inflation at bay, although the Central Bank has been gradually reducing them since 2003 to stimulate lending. ${ }^{22}$ The importance of maintaining a stable environment is therefore clear.With it, interest rates can continue to come down, fostering growth in alternative financing options like venture capital. If rates remain at their current level investors are likely to put their money elsewhere where returns are less risky (Jardim, 20I2).To reach the stated goal of I.8\% of GDP for combined public and private R\&D investment, it is essential that private sector investment in R\&D be increased to levels similar to those of developed countries. ${ }^{23}$

Along with lower interest rates, strengthening business incubators associated with universities can help achieve the goal of greater private sector involvement. The afore-mentioned 2004-2007 series of laws that loosened restrictions on university-business cooperation is an important start, as are the regulatory changes that facilitated the VC industry, which buys companies coming from these incubators. ${ }^{24}$ Incubators that have already proven successful include: CELTA, associated with the Universidade Federal de Santa Catarina, and CIETEC, associated with the Universidade de São Paulo.VC and business incubators bring value by reducing the "reliance on the government for financing and the promotion of an entrepreneurial spirit amongst researchers" (Castro, 20I2).

By bringing academia and business closer, venture capital and business incubators go some lengths to curtail another hindrance to innovation in Brazil. This is the perception by local business and universities that R\&D is a government supported affair. Although hard to quantify, this cultural feature has been mentioned by several experts on Brazilian innovation as a problem hindering the expansion of the sector. ${ }^{25}$ Researchers are described as lacking an entrepreneurial mindset and having a "research for research's sake mentality" (Jardim, 20I2). According to Jardim, in order to break with this paradigm it is necessary to have more widely successful cases of knowledge being turned into products. These should be publicized so that entrepreneurs and academia can appreciate the value of operationalizing knowledge, both for its competitiveness and human development benefits.

\section{Conclusion}

South Africa and Brazil have the potential to become important world players in innovative sectors. Both countries are not currently living up to their potential, however. Some constraints to growth are structural and/or external, but many of them can be alleviated by a more favorable policy environment. The paper has highlighted a number of areas where policy changes have already made a difference, using the venture capital industry in Brazil as an example. By implementing some of the suggested policy reforms, Brazil and South Africa can capitalize on their successes and ac- 
celerate innovation, the key to long-term development in both countries.

\section{References}

ABVCAP. 2012, Industry Overview:About the Sector, Portal ABVCAP, www.abvcap.com.br.

AGHION, P., Braun, M. and Fedderke, J. 2007. Competition and Productivity Growth in South Africa Harvard University, mimeo, Cambridge: MA.

ALMEIDA, R. and Fernandes, A. 2008. Openness and Technological Innovations in Developing Countries: Evidence from Firm-Level Surveys, Journal of Development Studies, Vol. 44 (5).

BERCOVITZ, J. and Feldman, M. 2007, Fishing Upstream: Firm Innovation Strategy and University Research Alliances, Research Policy,Vol. 36.

BLANKLEY, W. and Moses, C. 2009. Main Results of the South African Innovation Survey, Human Sciences Research Council (HSRC) Press, Cape Town.

BLOOM, N., Sadun, R. and Van Reenen, J. 20I2, Americans do IT Better: US Multinationals and the Productivity Miracle, American Economic Review, Vol. 102 (I

BRANDAO, V., Gonçalves, A., Ganem, C. and Dos Santos, E. 2006, Brasil Inovador: O Desafio Empreendedor: 40 Histórias De Sucesso De Empresas Que Investem Em Inovação. FINEP, http://download.finep.gov.br.

CASTRO, Christian. Personal Interview. 8 August 2012.

CHANDRA, V. and Kolavella. 2006. Technology, Adaptation, and Exports How Some Developing Countries Got It Right." in Chandra, V (Ed). Technology, Adaptation and Exports, The World Bank, Washington, DC.

CIMOLI, M., Dosi, G. Mazzoleni, R. and Sampat, B. 20II. Innovation, Technical Change and Patents in the Development Process: A Long Term View, LEMWorking Paper Series, Italy.

DE BRITO CRUZ, C and De Mello, L. 2006. Boosting Innovation Performance in Brazil, OECD Economics Department Working Papers, No. 532.

DE CARVAlHo, A., Netto, H. and Sampaio, J. 20I2, Private Equity and Venture Capital in Brazil:An Analysis of Its Recent Evolution, Social Science Research Network Working Paper Series, http://ssrn.com/abstract=1996729.
DE MORAIS, J. 2008, Capítulo 2: Uma Avaliação De Programas De Apoio Financeiro a Inovação Tecnológica Com Base Nos Fundos Setoriais e na Lei De Inovação, Políticas De Incentivo À Inovação Tecnológica: No Brasil. Brasília, IPEA: 67-I06, www.ipea.gov.br.

DEPARTMENT OF SCIENCE AND TECHNOLOGY, 20I I, www.dst.gov.za

DIRETRIZES DE GOVERNO, 20I2, www.planalto.gov.br

ECONOMIST, 2012,VC Clone Home, Economist Print Edition. June 2nd 2012.

EDLER, J. and Georghiou, L. 2007, Public Procurement and Innovation- Resurrecting the Demand Side, Research Policy, Vol. 36.

GOLDBERG, Kaplan, Kuriakose, Tuomi, Daniels and Draper, 20I I, Fostering Technology Absorption in Southern African Enterprises, World Bank.

IBGE, Instituto Brasileiro De Geografia E Estatística, 2010, Pesquisa De Inovação Tecnológica:2008, IBGE, www.pintec. ibge.gov.br.

JARDIM, Francisco. Personal Interview. 9 August 2012.

KAPLAN, D. 20 I 2,A Study on Manufacturing Productivity and Innovation in South Africa: A Comparison with the BRICS, African Development Bank (AFDB/CTR/SARC/2012/003).

KINOSHITA, Y. 1998. Technology Spillovers through Foreign Direct Investment, William Davidson Institute Working Paper No.22I, Prague, Czech Republic.

KORTUM, S. and Klette, T. 2004, Innovating Firms: Evidence and Theory, UCLA Department of Economics, Levine's Working Paper Archive.

LEAMON, A. and Lerner, J. 20I2, Creating a Venture Ecosystem in Brazil: FINEP's INOVAR Project', HBS Working Knowledge Series No. 7018, http://hbswk.hbs.edu.

LEDERMAN, D. 20 I0.An International Multi-level Analysis of Product Innovation, Journal of International Business Studies, Vol. 41 .

MACGARVIE,M. 2006. Do Firms Learn from International Trade?,The Review of Economics and Statistics, Vol. 88 (I).

MANI, S. 20II, Measuring Innovative Activities in Developing Countries: Conventional versus New Indicators, Global Academy Lecture, www.globelicsacademy.org 
MATIAS-PEREIRA, J. and Kruglianskas, I. 2005, Gestão De Inovação: A Lei De Inovação Tecnológica Como Ferramenta De Apoio Às Políticas Indutrial E Tecnológica Do Brasil, RAE-eletrônica Vol (4:2): I-2I, www.rae.com.br/eletronica.

MCTI, Ministério Da Ciência, Tecnologia E Inovação, 2012. Estratégia Nacional De Ciência, Tecnologia E Inovação 2012 - 20I5. MCTI website, www.mct.gov.br.

MOHNEN, P., Mairesse, J. and Dagenais, M., 2006. Innovativity: A Comparison across Seven European Countries, UNUMERIT Working Paper Series, Maastricht.

NOLAND, M., and Pack. H. 2003. Industrial Policy in an Era of Industrialization: Lessons from Asia, Institute for International Economics, Washington, DC.

REICHEIT, K. 2007. University Technology Transfer and National Innovation Policy: Success Stories from Brazil, Colombia and South Africa, International Intellectual Property Institute.

RODRIGUEZ, A., Dahlman, C. and Salmi, J. 2008, Knowledge and Innovation for Competitiveness in

Brazil,World Bank, Washington DC.

SAGGI, K. 2002. Trade, Foreign Direct Investment and Technology Transfer: A Survey, The World Bank Research Observer,Vol. 17 (2): 191- 235.

SALERNO, M., and Kubota.L. 2008, Capítulo I: Estado e Inovação, Políticas De Incentivo À Inovação Tecnológica No Brasil, IPEA: 13-66, www.ipea.gov.br.

SAVCA, 2010. 2010 SAVCA Venture Solutions VC Survey, South African Venture Capital and Private Equity Association.

SENNES, R. 2009, Innovação No Brasil: Políticas Públicas E Estratégias Empresariais, Woodrow Wilson International Center Paper,Washington, DC.

UNCTAD, 1995. World Investment Report: Transnational Corporations and Competitiveness, United Nations Conference on Trade and Development Publication, New York and Geneva.

\section{Notes}

3. A number of studies corroborate this link, finding that exporting is positively correlated with innovation at the firm level (Lederman, 2009; Almeida and Fernandez, 2008).

4. Aghion, Braun and Fedderke (2007) demonstrate that competition spurs innovation in South Africa. In fact, the high concentration in many industries appears to be constraining productivity. The authors argue that mark-ups are higher in South African industries than they are in corresponding industries elsewhere in the World and that a 10 percent reduction in mark-ups in South Africa would lead to an increase in productivity growth of 2 to 2.5 percent per year.

5. The anti-commons problem occurs when excessive fragmentation of property rights may slow research and prevent any one owner from commercialization of an innovation.

6. These include spirals for washing coal, pumping up water, hydropower, tracked mining, underground locomotives, ventilation, shaft sinking, and turnkey new mine design (Goldberg et al, 20II).

7.The IDC now invests directly, but previously played an important role in stimulating a private $\mathrm{VC}$ class, by acting as limited partner to local VC managers.

8. An analysis using NIS data confirmed some important points in the literature and in the interviews. It appears that innovation is correlated with: stronger IPR, collaboration with other firms, exports, firm size (particularly due to the financial constraints suffered by SMMEs), and managerial skill levels. Collaboration with (i) other sister-firms in an enterprise group, (ii) suppliers of equipment, materials and (iii) clients or customers are ALL positively and significantly correlated with R\&D (Goldberg, 20I I).

9. Qualifying scientific and technological research and development activities are "...the generation of new knowledge, the discovery of novel, practical and non-obvious information of a scientific or technological nature; or the devising, developing or creating of any invention, design or computer program of a scientific or technological nature (Department of Science and Technology, 20I I).

10. For example: Small Business Innovation Research (SBIR) Program (US), TEKES (Finland), OCS (Israel), and CSIRO (Australia).

I I. FINEP can be translated to "Financier of Studies and Projects".

12. These funds act in the following sectors: Aeronautics, Agribusiness, In the Amazon Region, Waterways, Biotechnology, Energy, Space, Water Resources, Information Technology, Mineral, Oil and Gas, Health, Land Transportation, lastly, Telecommunication (Sennes, 2009:16).

13. The Brazilian state is still responsible for around $60 \%$ of expenditures on R\&D while the private enterprise for only $40 \%$ (Salerno, 2008: 24) 
14. The 2004 Innovation Law (Law 10,973 of December 2nd 2004) was the cornerstone of the series of legal changes of the period.

15. Imposto sobre Produto Industrializado, translated to tax on industrialized goods.

16. Including:Arbix, De Negri, Jardim and Castro.

17.Associação Brasileira de Private Equity \& Venture Capital, translated to Brazilian Private Equity and Venture Capital Association.

18. Such as the Law 10,973 of December 2nd 2004, as previously mentioned.

19. Law II,3 I 2 of June 26st, 2006.

20.Translates to Comissão de Valores Mobiliários.

21.With back-to-back letter of credits, exporters were able to open accounts in a local bank for the import of inputs against the export orders placed in their favor by the final clothing importers. The cost of the imported items along with interest and other charges would be deducted by the local bank from the proceeds of the sales of the final output.

22. The Central Bank of Brazil's overnight rate has gradually dropped from 26.5\% in April 2003 to 8\% in May 2012 (Central Bank of Brazil, 2012).

23. The government's target for private sector investment is $0.9 \%$ of GDP by 2014 , which is looking increasingly unattainable given current levels (MCTI 20I I: I48).

24. According Anprotec, the growth of business incubators in Brazil has gone from two such organizations in 1988 to around 400 in 2008.

25. Glauco Arbix, Christian Castro and Francisco Jard. 